Erratum

\title{
Erratum: Kadhim, I.; Abed, F.M. The Potential of LiDAR and UAV-Photogrammetric Data Analysis to Interpret Archaeological Sites: A Case Study of Chun Castle in South-West England. ISPRS Int. J. Geo-Inf. 2021, 10, 41
}

\author{
Israa Kadhim 1,*iD and Fanar M. Abed ${ }^{1,2}$ (D) \\ 1 Environment and Sustainability Institute, University of Exeter, Penryn Campus, Penryn, Cornwall TR10 9FE, \\ UK; fanar.mansour@coeng.uobaghdad.edu.iq \\ 2 College of Engineering, University of Baghdad, Baghdad 10001, Iraq \\ * Correspondence: ik281@exeter.ac.uk
}

Citation: Kadhim, I.; Abed, F.M. Erratum: Kadhim, I.; Abed, F.M. The Potential of LiDAR and UAV-Photogrammetric Data Analysis to Interpret Archaeological Sites: A Case Study of Chun Castle in South-West England. ISPRS Int. J. Geo-Inf. 2021, 10, 41. ISPRS Int. J. Geo-Inf. 2021, 10, 552. https:// doi.org/10.3390/ijgi10080552

Received: 5 July 2021

Accepted: 8 July 2021

Published: 16 August 2021

Publisher's Note: MDPI stays neutral with regard to jurisdictional claims in published maps and institutional affiliations.

Copyright: (c) 2021 by the authors. Licensee MDPI, Basel, Switzerland. This article is an open access article distributed under the terms and conditions of the Creative Commons Attribution (CC BY) license (https:// creativecommons.org/licenses/by/ $4.0 /)$.
The authors would like to make the following corrections to the published paper [1]. The changes are as follows:

Replacing the Acknowledgments:

The authors would like to thank the UK Centre for Ecology \& Hydrology for providing LiDAR data. We are grateful to Ann Preston-Jones from Historic England, Trewern at Trehyllys Farm and Andrew Hitchings at Carn Farm for giving permission to undertake the experiment at Chun Castle. The Leica GS08 GNSS was supplied by the University of Exeter Environment and Sustainability Institute (ESI) DroneLab. We would also like to thank Karen Anderson and Andrew Cunliffe for flying a drone over the study site and for their comments on earlier version of this paper. Also, big thanks to English for Academic Purposes (EAP) tutors, Isabel Noon and Richard Little, from the University of Exeter for providing feedback on organization and flow of ideas of this Manuscript. Finally, special thanks to CARA for the studentship stipend.

With:

The authors would like to thank the UK Centre for Ecology \& Hydrology for providing LiDAR data. We are grateful to Ann Preston-Jones from Historic England, Trewern at Trehyllys Farm and Andrew Hitchings at Carn Farm for giving permission to undertake the experiment at Chun Castle. The Leica GS08 GNSS was supplied by the University of Exeter, Environment and Sustainability Institute (ESI) DroneLab. We would also like to thank Karen Anderson and Andrew Cunliffe for contributions to conceptualization, methodology, data collection, data analyses, and writing. Moreover, big thanks to English for Academic Purposes (EAP) tutors, Isabel Noon and Richard Little, from the University of Exeter for providing feedback on the organization and flow of ideas of this manuscript. Finally, special thanks to the University of Exeter and CARA for the studentship stipend.

Funding: This research received no external funding.

Institutional Review Board Statement: Not applicable.

Informed Consent Statement: Not applicable.

Data Availability Statement: The data used to support the findings of this study are available from the corresponding author upon request.

Conflicts of Interest: The authors declare no conflict of interest.

\section{Reference}

1. Kadhim, I.; Abed, F.M. The Potential of LiDAR and UAV-Photogrammetric Data Analysis to Interpret Archaeological Sites: A Case Study of Chun Castle in South-West England. ISPRS Int. J. Geo-Inf. 2021, 10, 41. [CrossRef] 